\title{
Primary Vitreoretinal Diffuse Large B-Cell Lymphoma
}

National Cancer Institute

\section{Source}

National Cancer Institute. Primary Vitreoretinal Diffuse Large B-Cell Lymphoma. NCI

Thesaurus. Code C157067.

An uncommon and potentially fatal diffuse large B-cell lymphoma that involves the uvea, retina, vitreous body, and optic nerve. It is a subset of primary central nervous system diffuse large B-cell lymphoma. 